University of South Florida

DIGITAL COMMONS

Digital Commons @ University of

@ UNIVERSITY OF SOUTH FLORIDA

South Florida

Government and International Affairs Faculty

Publications

Government and International Affairs

2012

\title{
Framing Non-Whites and Producing Second-Class Citizens in France and Portugal
}

\author{
Bernd Reiter \\ University of South Florida, breiter@usf.edu
}

Follow this and additional works at: https://digitalcommons.usf.edu/gia_facpub

Part of the Government Contracts Commons, and the International Relations Commons

\section{Scholar Commons Citation}

Reiter, Bernd, "Framing Non-Whites and Producing Second-Class Citizens in France and Portugal" (2012). Government and International Affairs Faculty Publications. 7.

https://digitalcommons.usf.edu/gia_facpub/7

This Article is brought to you for free and open access by the Government and International Affairs at Digital Commons @ University of South Florida. It has been accepted for inclusion in Government and International Affairs Faculty Publications by an authorized administrator of Digital Commons @ University of South Florida. For more information, please contact digitalcommons@usf.edu. 


\section{University of South Florida Scholar Commons}

Government and International Affairs Faculty

Publications

Government and International Affairs

2012

\section{Framing Non-Whites and Producing Second-Class Citizens in France and Portugal}

Bernd Reiter

University of South Florida, breiter@usf.edu

Follow this and additional works at: http://scholarcommons.usf.edu/gia_facpub

Part of the Government Contracts Commons, and the International Relations Commons

\section{Scholar Commons Citation}

Reiter, Bernd, "Framing Non-Whites and Producing Second-Class Citizens in France and Portugal" (2012). Government and International Affairs Faculty Publications. 7.

http://scholarcommons.usf.edu/gia_facpub/7 


\title{
Framing Non-Whites and Producing Second-Class Citizens in France and Portugal
}

\author{
Bernd Reiter
}

The quality of contemporary democracies hinges on the breadth and depth of the citizenship regimes on which democracy ultimately rests. This article argues that, to assess citizenship, two important dimensions are of crucial interest, namely to what extent formal citizens are able to live and practice substantive citizenship roles and, secondly, how access to citizenship rights is used by different societal groups in order to defend privilege. Having conducted a comparative case study of Portugal and France, I now argue that political elites are contributing to a framing of non-whites as foreigners and immigrants because it serves their purpose and that of the majority of their electorate. I also demonstrate how academia contributes to this framing, as many scholars seem unable to free themselves from biased academic traditions, some of which are clearly racist.

Keywords: Portugal; France; Citizenship; Racism; Minorities

\section{Introduction: Second-Class Citizenship}

Civilization has not yet fully recovered from the shock of its birth-the transition from the tribal or 'closed society' with its submission to magical forces, to the 'open society', which sets free the critical powers of man. [...] the shock of this transition is one of the factors that have made possible the rise of those reactionary movements, which have tried, and still try, to overthrow civilization and return to tribalism (Karl Popper 1962)

In recent years, the discourse about democracy has shifted from a focus on transition, to consolidation, and lately on the quality of democracy (O'Donnell et.al. 2004). Most authors follow the path-breaking work of T.H. Marshall (1992 [1950]) and focus on citizenship rights as a way to assess democratic quality (e.g. Hagopian 2007). Others, more specific, argue that we need to take a close look at civil rights in order to determine the quality of democracy (Fischer 2008; Holston 2008). This focus on civil rights has significantly added to our understanding of what is wrong with democracies deemed to be 'wanting' or 'missing something'. However, the almost exclusive focus on rights has led our view away from the original meaning of citizenship, composed not just of rights, but also of responsibilities. In addition, this discourse on rights has furthered an understanding that, as citizens, we are entitled to a set of rights and has led many to discuss how far these rights should stretch-for example, whether or not they should include social and cultural rights (Young 1990).

Bernd Reiter is Associate Professor of Comparative Politics at the University of South Florida. Correspondence to: Dr B. Reiter, University of South Florida, 4202 E. Fowler Avenue, CPR 107, Tampa, FL 33620, USA. E-mail: breiter@usf.edu. 
I argue that an exclusive focus on citizenship as a set of rights is misguided and analytically not helpful. I agree with Dworkin (1978), who argues that the only right we have is that of equal treatment. Citizenship consists of rights and responsibilities, where rights are not entitlements, but certain collectively enforced protections and guarantees. Furthermore, citizenship consists of duties towards the collective which, in a democratic regime, translates into responsibilities towards the rules and contents of democracy. Accepting this broader definition of citizenship allows us to better assess the quality of democracy by analysing the quality of its citizenship-in terms both of rights and of responsibilities.

By broadening the focus towards rights and responsibilities, we are able to compare a broader spectrum of democracies along a greater scale of indicators. Although some more-consolidated democracies have been able to guarantee a broad set of rights to their citizens, they score low when it comes to citizen responsibilities. Others, typically of the less-developed world, have been unable to guarantee rights, but they demand-and can sometimes count on-high degrees of citizen action and participation, which significantly adds to an active citizenship and thus to citizenship responsibility (Avritzer 2009).

Typical scenarios also include a separation, among the citizenry, between those who have rights and those who have responsibilities. Some privileged groups have been able to secure rights without sharing in the responsibilities; other groups have been left with responsibilities, without having access to the same rights (most notoriously in the case of women, non-traditional citizens and minorities). The distinction of who has rights and who does not-as well as the related differentiation between those on whose responsibilities the state relies, and those who avoid these responsibilities-is highly consequential. Citizenship status, ethnicity, class and gender, have been used to divide citizenry into those with and those without rights, and those with and those without responsibilities.

\section{Substantive Citizenship as a Social Role and Relational Asset}

In his seminal work entitled Citizenship and Social Class, Marshall (1992[1950]) argued that, in Europe, civil rights preceded political rights and that, once both these rights were achieved, social rights would follow. Marshall predicted that the twentieth century would see an expansion of social rights which he defined as the whole range from the right to a modicum of economic welfare and security to the right to share to the full in the social heritage and to live the life of a civilized being according to the standards prevailing in society. The institutions most closely connected with it are the educational system and the social services' (Marshall 1992[1950]: 8). For him, the state was called upon to reduce the risks associated with capitalism for the poorest citizens, state action which would lead to an 'overarching sense of community and civilization' (Jones and Gaventa 2002: 3).

When the twentieth century came to an end, it became clear that Marshall's prediction was too optimistic. In 2009, many European citizens are effectively still excluded from social rights, to the point where some analysts argue that Europe is developing an apartheid system (Balibar 2004). Non-traditional, non-white European citizens, in particular, see their 
civil rights curbed by the forces of prejudice and racism. In many countries they are treated as foreigners and intruders despite their legal citizenship (Rosello 2001). Instead of social rights following civil and political rights, it rather appears that the exercise of civil rights depends on the previous achievement of social rights, as racism is undermining the effectiveness of civil and political rights of all those stigmatised as 'Others Within'.

Racism is at the core of this exclusion and it is Marshall's underestimation of the power of racism that led him to formulate overly optimistic predictions about Europe's democratic future. In Europe, as elsewhere, racism continues to be functional for the maintenance and reproduction of privilege. Worse, with the increased market competition characteristic of advanced capitalist systems, the importance of racism might grow. Racism becomes more pronounced when different actors compete for scarce, and thus highly desirable, goods (Winant 2001). Under such conditions, whiteness functions as an additional capital, bestowing competitive advantages on those able to claim it with success (Reiter 2009).

Citizenship is a broad concept. According to Webster's definition, it is 'the status of being a citizen'. Marshall (1992[1950]: 18), in turn, defines citizenship as 'a status bestowed on those who are full members of a community. All who possess the status are equal with respect to the rights and duties with which the status is endowed'. Tom Bottomore, who wrote the essay 'Forty Years On' which, together with Marshall's own essay, comprises the publication through which Marshall's work is accessible (1992), already points out that citizenship 'in our days' (his were the days of the 1990s) faces new challenges, some of which Marshall could not have foreseen. Among others, he mentions the problems triggered by increased migration, which thus cause greater ethnic heterogeneity among European citizenry and pose new challenges to citizenship. To capture these new challenges, Bottomore proposes a distinction between formal and substantive citizenship-a distinction introduced by Brubaker $(1989,1992)$. He quotes Brubaker, who had argued that 'Formal citizenship is neither a sufficient, nor a necessary condition for substantive citizenship' (Brubaker, quoted in Bottomore 1992: 66).

Several authors have disputed the notion of citizenship as a status. For communitarians such as Sandel (1998), citizenship, more than a right, is an obligation and a calling to participate and actively engage in one's community. Civic republicans such as Habermas (1998) have stressed that what makes one a citizen is the ability to participate in collective decisionmaking and thus to fulfill one's role as an active constituent of popular sovereignty. According to Jones and Gaventa, 'At the centre of much contemporary writing is the need to conceptualize citizenship as both a status, which accords a range of rights and obligations and an active practice' (2002: 5). Since then, others have tried to expand the notion of citizenship and have proposed alternative ways of conceptualisation. Somers, for example, has defined citizenship as 'a set of institutionally embedded social practices' (1993: 589). More-recent treatments of citizenship-e.g. those collected in Tulchin and Ruthenberg (2007)_follow this focus on citizenship as a practice. Holston proposes 'to study the full experience of citizenship, and not only its political aspect' (2007). In his book 
Insurgent Democracy, Holston (2008) indeed applies an anthropological framework to the analysis of how citizenship is experienced in everyday life.

However, these recent efforts to adequately capture and explain what citizenship effectively is and what it means to different people have not yet produced a conclusive framework and Hagopian's (2007) call to focus on citizenship, especially when studying such 'disjunctive democracies' (Holston 2008), where political and civil rights do not necessarily go hand-in-hand, still stands.

To define citizenship, we therefore first need a useful analytical framework-a lens that allows us to focus on and delineate what the word 'citizenship' stands for. I propose to accept Brubaker's distinction of formal and substantive citizenship and, in this article, further elaborate on the meaning of substantive citizenship. What exactly is substantive citizenship and how can we, as social researchers, assess it? Substantive citizenship, I propose, has two important dimensions: as a social role and as a relational asset. Indicating the relative presence or absence, as well as the quality of possession, on both dimensions allows us to gain a deeper, more specific, more precise and hence more accurate and valid, capturing of the empirical reality represented by the concept of citizenship.

Hence, I propose that the concept of citizenship and the rights associated with it have two important dimensions as yet unexplored, or rather, not yet applied systematically to the study of democracy. First, citizenship is not just a legal status; it needs to be a practical and practiced reality for it to have any impact on people's lives. As such, citizenship is associated with the role of being a citizen invested with certain rights and duties and protected by the state that makes and enforces the rules and laws that define citizenship. Citizenship, then, is best understood as a social role, as Brazilian anthropologist da Matta (1987) has long pointed out, and Holston (2008) has more recently highlighted again. If some citizens are not treated as citizens, citizenship remains an empty concept. Second, citizenship is also an asset and, just like any other asset, it is disputed. As an asset, the value of substantive citizenship is relational, i.e. its value is derived from how much substantive citizenship one person or group has, compared to another person or group. Having access to the asset of citizenship when most people do not, bestows extra value onto its possession. ${ }^{1}$ Treating citizenship as a relational asset implies that its unequal distribution divides the citizenry, and privileges those able to claim more citizenship than others and, through this process, secure tangible advantages for themselves.

Seen in this light, the widely used concept of exclusion gains a more precise meaning - exclusion from having full access to citizenship rights and being able to fully live the role of a citizen. This exclusion, then, is mirrored by the inclusion of all those who are able to claim citizenship roles for themselves, using this access as a tool to defend privilege and perceiving the roles as entitlements.

\section{France: Double Standards}

In France, republican traditions of universal rights and liberties have dominated official political discourse since the French revolution. After the breakout of 
minority youth riots in early November 2005, Prime Minister Villepin asserted that 'France is not a country like others. It will never accept that citizens live separately, with different opportunities and with unequal futures'. ${ }^{2}$ The way the French state seeks to ensure equal opportunities is guided by its commitment to the republican ideas of citoyenneté and intégration, which point to assimilation as the only way to integrate immigrants and non-traditional citizens into the nation. The core of this philosophy is to not recognise differences among French citizens and to apply colour-blind public policies to ensure equal opportunity.

However, the assertion of the French Prime Minister is in stark contrast to a French reality that has been depicted by many as increasingly separate, where people of different ethnic backgrounds encounter very different opportunities and face highly disparate futures (Balibar 2004). France has become a showcase and example for a more-dominant European policy of not recognising ethnic groups and minorities and focusing on assimilation as the main, and indeed only, way to integrate immigrants. Officially, once a citizen, the French state does not take account of any group-specific characteristics that de facto set the citizenry apart, such as ethnicity, religion or gender. The French state therefore insists on a form of radical individualism that is anchored in political liberalism and classical republicanism. This model is dominant all over continental Europe and the importance of understanding the French way of officially denying the very existence of minorities therefore extrapolates the borders of the Fifth Republic.

In real life, the distinction of insider/outsider that regulates national belonging and the distribution of rights is negotiated through the construction of a racialised conception of community. Nationalist political groups rediscover and disseminate a myth of 'purity', detecting 'foreign' elements that 'contaminate' the national body. Thus, whereas French political elites insist on not officially recognising any minorities within the national body, cultural, ethnic and religious differences are routinely recognised in everyday interactions and are extremely consequential. In a survey conducted in 2007 by SOFRES - the most renowned and largest market-research firm in France' (Tin 2008: 36) -a total of 3.86 per cent of adults interviewed selfdeclared as 'black'. Of those, 56 per cent declared that they had experienced racism in their everyday lives. ${ }^{3}$ Research has further demonstrated that young blacks (classified in the surveys as secondgeneration Maghrebins and sub-Saharan Africans) are 2.5 times more likely to be unemployed than their white counterparts, which means that their unemployment rate hovers at around 20 per cent. Although non-whites also drop out of school more often than whites, their difficulty in finding jobs remains, even when compared to whites with the same qualifications (Silberman et al. 2007).

The racist and exclusionary practices responsible for this situation are not hard to decipher as anxious responses of traditional, white residents towards a changing environment. As noted above, white French benefit from the exclusion of non-whites, especially on the job market, where high unemployment also affects them. Given the evidence of discrimination and unequal treatment affecting French citizenry depending on their skin colour and religion, how can we explain that the French state insists on not 
providing statistics that capture these inequalities? Established practices around the job market provide a first clue: it is common practice in France, as elsewhere in Europe, for curricula vitae to contain information about the age of the applicant, as well as a photo. The black French citizens I interviewed in 2007 had all experienced similar situations when applying for a job-their candidacy advanced up to the moment when it became obvious that they were black.

The statement of one black female interviewee-age 28, holder of a university degree, born in France and a French citizen-was typical. She explains (after my question regarding situations where racism was the most influential):

\footnotetext{
At work, especially when you apply for a job. At job interviews, I would always be asked where I was from. I am French, but to them, it doesn't appear that way (interview Rouen, 26 February 2007).
}

On average, the black French citizens I interviewed in 2007, all of whom held university degrees and were French citizens, took about three years to finally find a job. In most cases, they found jobs that did not meet their expectations - a finding confirmed by more-systematic research (Simon 2003).

The French state thus demands or at least tolerates the fact that job applicants need to give evidence of their skin colour when applying for work, fully aware that this will significantly (and probably negatively) impact on their chances. In other words, French political elites and the state they command are aware that traditional white French citizens routinely discriminate against non-whites and non-Christians, a conclusion that is further evidenced by the long history of half-hearted and thus ineffective measures taken by the state to at least formally address this issue (Kiwan 2007). But those same elites avoid taking any concrete and effective action to counteract this situation with reference to the ideal of universalism, laïcism and republicanism, although all of these ideals were formulated precisely to ensure equality, brotherhood and liberty. So why have political elites in France not acted more decisively to ensure the quality of their democracy and the upholding of the high principles it represents? The most plausible answer, it appears, is that they do not want to. Prohibiting the excluded from using cultural, ethnic and religious criteria to address inequalities while, at the same time, allowing employers to use ethnic criteria in their hiring practices, reveals the deep bias with which political elites address this issue. The conclusion reached by Louis-Georges Tin, black activist and founder of Cran, an umbrella organisation for black associations in France, seems the most plausible:

\footnotetext{
I must note that the fierce adversaries of communities, as a matter of fact, were not against communities as such; they were against some communities: Arab-Muslims, Jews, and homosexuals [...] no one criticizes the sixteenth arrondissement in Paris, a bourgeois community which also has its particular habits, mores, and customs. No one would dream of criticizing the traditional communities, professional communities, and the Catholic communities (Tin 2008: 38).
} 
French political elites know about the discriminatory practices that victimise a part of the French citizenry yet they do not act decisively to resolve them. Instead, they hold on to the rhetoric of universalism, even though its aim is also to ensure equal rights for all. French citizenship has, as a consequence of persistent discrimination, become racialised and divided. Whereas traditional white citizens insist on their citizenship rights, thus treating them as assets and entitlements, ethnicised non-traditional minorities have become second-class citizens who are not allowed to experience the full extent of their role. To them, citizenship is not a set of entitlements but an unfulfilled promise.

It is not surprising that people seek to defend privilege, especially if unmerited, and when it promises to secure concrete and very important advantages - for example, on a very competitive job market. It is, however, the responsibility of political elites and state apparatuses to check these tendencies and enact policies that aim to ensure equal opportunities-the core of the universalist idea. Instead, French political elites are assisting white citizens to defend their racial privileges, thus revealing profound double standards. If the French state is so sternly against any form of particularism, then the ethnic marking of applicants on their curricula vitae should be illegal, especially considering its highly consequential effects on (universalist) equal opportunities. Racist bias in hiring would also have to be addressed in other ways in order to ensure equal chances, for example by enacting quotas. Furthermore, if state elites were really committed to achieving universal equality, they would not rob those negatively affected by discriminatory practices of the means to address them. They do this by not allowing a diagnosis of the current situation of the French citizenry-that takes account of inequalities-in the form of colour-conscious censuses. French political elites, however, have not done anything to effectively counteract the racist practices of traditional white citizens. This reluctance can only be explained by remembering the benefits that political elites and their electorate reap from the current situation: it provides the white majority with a competitive advantage on the job market, allows state elites to escape scrutiny and shields them from being held responsible for the wide array of social problems facing French society by blaming Others.

\section{Portugal: Others into Foreigners}

Portuguese society is increasingly heterogeneous, although there are no data on how heterogeneous its population truly is, as the Portuguese state follows the French model of not differentiating between its citizens. However, cities such as Lisbon count on a significant population of non-white citizens who go to school with, and compete for jobs against, the dominant white population. After examining the role of state elites in the creation and maintenance of a racist common sense that leads to racialised conceptions of first- and second-class citizenship, the case of Portugal allows us to shed light on the implication of academia in this maintenance which frames non-whites as foreigners and immigrants, while deciding who 'fits in' based on ethnic background. I present two arguments here to elucidate this phenomenon: first, the fact that there are almost no studies on blacks in Portugal, despite their visibility in cities like Lisbon and 
Porto; and second, the fact that some immigrants-those labelled 'home-comers' or retornados-are much more welcome and taken care of than others, an attribute with strong racial undertones.

The literature about blacks in Portugal or on the situation of minorities there is scarce, and there are almost no publications on the topic. ${ }^{4}$ Instead, it is very common to read that 'Portugal is a fundamentally homogeneous country in terms of ethnicity and language, and also as regards religious faith' (Freire 2007: 208). This goes against all the empirical evidence from Lisbon when we know from research that 'legally settled foreigners represent around 5 per cent of the resident population' (Marques et al. 2007: 1149). Furthermore, research on education by these same authors who, in 2004, conducted a case study in the municipality of Oeiras, Greater Lisbon, allows us to deduce the degree of heterogeneity that characterises contemporary Lisbon society. Marques et al. found that, among their sample of Oeiras schoolchildren aged 14 to 24 , ' 44.3 per cent [were] [...] children of immigrants' (2007: 1156). At the same time, articles and books about immigrants abound, thus creating the false impression that Portugal has indeed an immigration problem, but not a problem of ensuring equal opportunities to its diverse citizenry.

So what kind of scholarly blindness allows social scientists to state that Portugal is a fundamentally homogeneous country? It appears that the lack of statistics on the presence and situation of minorities among the Portuguese citizenry has become a self-fulfilling prophecy. By focusing academic production on foreigners and immigrants while, at the same time, not producing any information on the number of minorities, let alone on their socio-economic situation, Portuguese scholars help to perpetuate a common sense that says 'Portuguese citizens are white; non-whites are foreigners and immigrants'. Similar to the French case, the interest behind such manoeuvering is quite evident: real problems remain unexamined and important questions unaddressed; political elites escape scrutiny by shifting the blame onto others, which allows them to continue in their malpractices; whites, perceived as 'normal citizens', benefit from the bedeviling of non-whites and reap tangible benefits.

In the case of Portugal, where funding for scholarly work in the social sciences is scarce and almost 100 per cent comes directly from different state agencies or from the state-owned Foundation for Science and Technology (FCT), it becomes clear that intellectual elites depend on state elites for the funding of their research projects (http://alfa.fct.mctes.pt/estatisticas/global). The fact that there are so few studies on ethnic minorities, especially blacks, in Portugal thus cannot be interpreted as a coincidence. To the contrary, the only two possible explanations for this omission are that (a) the state does not fund such studies, or (b) that Portuguese researchers do not propose any projects about Portuguese ethnic diversity in relation to equal opportunities and questions of justice. Both possibilities seem plausible and deserve further scrutiny. For the sake of my study, it is enough to point to the inherent conservativism and inertia of scientific research programmes, favoring research projects that are within already established paradigms. This tendency complicates the emergence of new research projects that are unconnected to already-established truths and the methods, units of analyses, and research questions associated with them (Kuhn 1996; Popper 2002). Scholars thus share in the responsibility of perpetuating the invisibility of ethnic minorities in Portuguese society-which, in turn, contributes 
to the perpetuation of their situation of exclusion and second-class citizenship status.

According to the extremely scarce information available, second-generation immigrants (a doubtful denomination in itself), fare much worse in school compared to their white counterparts. Marques et al. found that 'Africans have gained the status of "the most visible minority". Surveys show that they are more prone to be perceived as immigrants than any other category [...] They are still the least welcome in close family relations'. They also found that 'nearly three quarters of students with Cape Verdean ancestry experienced grade blockage at least once' (Marques et al. 2007: 1149, 1160). In other words, 75 per cent of 1424-year-old students in Oeiras with a Cape Verdean background repeat a year at least once before they graduate from High School!

'In Oeiras, we found that around a third of the Portuguese students have to repeat a school year at least once, compared to 41 per cent for native-born children of immigrant parentage and 51 per cent for the foreign-born' (Marques et al. 2007: 1158). There are also extreme differences among 'native-born children of immigrant parentage' and those born to traditional Portuguese residents with regard to early school determination, despite the fact that the majority of Portuguese students (77 per cent, according to Marques et al. 2007) aspire to attend university. Hortas (2008) confirms these findings, at least indirectly, when stating that 'When we look at immigrant dropout/failure, we see that the rates are triple the norm in primary school, and double for the other cycles' (2008: 423).

The use of such extremely cumbersome designations as 'native-born children of immigrant parentage' hints at the difficulties that Portuguese scholars face when discussing this issue. When reading through the available educational statistics and the research conducted in this field, it appears that what schoolchildren who face above average dropout and repetition rates indeed share is not their legal status but the colour of their skin. They are all non-white and, even though Portuguese is their first language, they perform significantly worse than their white Portuguese colleagues and even white EU immigrants (Marques et al. 2007). In other words white foreigners, whose first language is not Portuguese, by far outperform black Portuguese schoolchildren whose first language is Portuguese.

The relative absence of studies about the socio-economic situation of Portuguese minorities, especially blacks, and the cumbersome treatment and reluctance with which they are treated together with the high profile of studies that focus on immigrants, all help to consolidate the already wide-spread common sense that transforms black Portuguese citizens into foreigners. The statement of an interviewee illustrates this state of affairs:

I am a Portuguese citizen but at the same time I am not a Portuguese citizen. I have all the rights, but at the same time, I have none. I have even represented Portugal at international events, while I was a student. But because of my colour, I am not treated as a citizen. I constantly experience discrimination at all levels: social, cultural, economic ... I compete in the job market against Portuguese classmates who had worse grades, but they get the job. ${ }^{5}$

Who counts as a national and who does not thus has severe consequences on life-chances in both France and Portugal-no matter the citizenship status. "Nationals must be white"-informs the common sense-a common sense that obfuscates all the inequalities and injustices to which non-white citizens are 
routinely exposed, while at the same time securing privileges to white citizens, and relieving political elites of their responsibility to ensure justice and equality among their citizenry-the cornerstones of democracy. After all, 'Blacks do not belong here' and, perceived as foreigners, are not a concern of political elites and the white majorities they represent.

\section{Ties to the Motherland: Of Remittances and Returners}

A final piece of empirical evidence of the construction of extremely biased racial regimes in Portugal is provided by the curious case of the so-called 'homecomers' or retornados-white African immigrants who settled in Portugal mostly between 1974 and 1975. When Portugal's African colonies achieved independence in 1974, many white colonisers ran the risk of losing their privileges and maybe even their properties and lives, and some 800,000 decided to move to Portugal. These white home-comers encountered such a welcoming and open Portugal that the whole experience was widely praised as a 'great success story' of integration (e.g. by Pires 2003). The willingness of the Portuguese society and state to accommodate these immigrants went so far as to alter a long-established legal tradition-the naturalisation law-which, since 1981 and in order to accommodate the returning colonisers now gone astray, was changed from jus soli to jus sanguini. After the changes of 1981, a child born to a Portuguese parent automatically becomes a Portuguese citizen, provided the parent was born in Portugal or in a territory administered by the Portuguese state. $^{6}$

Since 1981, Portugal thus welcomes all those able to claim Portuguese ancestry while, at the same time, blocking the integration of all those without it. Through this manoeuvre, returners were not considered as immigrants. The success of this re-integration, according to Pinheiro, was due to the fact that 'this biographical particularity of this community is not visible in Portuguese society' (Pinheiro 2008: 66). Read: They were white. Pinheiro continues: 'With the retornados also came approximately 28,000 Africans, both refugees from the civil wars in Angola and Mozambique and working immigrants from all former colonies. Unlike the retornados, this African community had no special connection to Portugal or Portuguese nationality since they came from independent states' (2008: 67) -no connection other than having worked for the Portuguese colonial empire and, as a consequence of betting on the wrong side, having lost a home in the newly independent African states, one might add. Indeed, a significant number of this early group of Africans most probably held Portuguese passports, because they had worked on the side of the colonisers, helping to control and administer the 'natives', a fact that can easily be verified by interviewing this population. Indeed, as Marques et al. (2007) indicate, some of these 'returners' have lived in Africa for generations. The maintenance of cultural ties to the colonial motherland has proved extremely consequential to them so that, in contemporary Portugal, the divisions created under colonial rule between colonial subjects and colonisers still plague intra- and inter-ethnic relations (Reiter 2008). It also seems legitimate to deduce that the dual labour market that determines the opportunities available to African migrants and their descendents, diagnosed by Eaton (2001), can in part be explained by the relation of different African-descent groups to the Portuguese colonial state. In an interview 
conducted in 2003, the president of the Lisbon-based Cape Verdean association, Ms. Alestina Tolentino, explained:

\begin{abstract}
After independence, many Cape Verdeans settled in Portugal. They were Cape Verdean nationals, but they had worked for the Portuguese state in Cape Verde. As such, they had acquired certain rights, pensions, social security, and such, which they had because they were Portuguese citizens. So when all these returners arrived in Portugal after independence, among them were many Cape Verdeans. They were highly qualified because they had worked for the Portuguese colonial apparatus [...] The face of colonialism for many Angolans and Mozambicans was not Portuguese, but Cape Verdean.
\end{abstract}

Most returners moved to Portugal because of the links they had forged during colonial times, when they had a direct connection to the colonising state apparatus. Once in Portugal, they could count on pensions and social security schemes. They felt, and most of them also officially were, Portuguese citizens and all those who were not would become so after 1981. If they were Cape Verdean nationals, they would still fit the racial regime that was created during colonial times and then employed to construct social hierarchies in Portugal, as most Cape Verdeans are easily distinguishable from Angolans and Mozambicans by their lighter skin colour.

As Reiter (2008: 403), explains:

\begin{abstract}
Under the indigenous law code that regulated life in most of the Portuguese world until 1961, some natives could become Portuguese citizens if they passed the 'civilization-test', consisting of demonstrating their degree of assimilation to European values and manners. The Indigenous Code of 1954 regulated the stages that led from being 'indigenous' to becoming 'civilized', making the achievement of European manners and habits the benchmark for gaining access to Portuguese citizenship rights. Assimilated Portuguese citizens had to demonstrate that they had left their 'native savagery' behind. Successful assimilation had to be proven through Portuguese language skills, clothing style, food habits, and other western civilized manners.
\end{abstract}

After 1974, Portuguese state elites thus 'took care of theirs' and, in so doing, made sure that uncivilised Others could not slip in.

However, the maintenance of bonds with individuals and groups who have connections to the motherland is a not uncomplicated matter, especially for Portugal, a country that had long argued its intimate closeness to its colonial subjects. Portuguese settlements in Brazil, Angola, Mozambique, Guinea-Bissau, Goa, Macao, South Africa and Cape Verde reach back to the sixteenth century. The Portuguese presence never effectively ended with independence, so that most of the former colonies still have a sizeable Portuguese population. By the late 1990s, the economic boom that was caused by Portugal joining the EU and receiving millions of EU funds to improve infrastructure started to slow down and unemployment began to rise. During that time the first studies about remittances emerged. From the late 1990s onward, remittances declined steadily from 3 per cent of GNP in 1990 to 2.5 per cent by the end of the decade. ${ }^{7}$

While colonial ties seemed to presume that Portugal would take care of all those who had helped to sustain the colonial apparatus by facilitating their integration into the Portuguese state, it became clear by the late 1990s that Portugal could not welcome all those communities that upheld their Portuguese nationality. Under these new economic circumstances, and equipped with hard evidence about the magnitude and importance of remittances for the Portuguese 
economy, Portuguese political elites shifted gear. They realised that it was no longer desirable to 'bring home' all the former colonisers or those who had passed the 'civilisation test' and could count on national solidarity, based on their white skin or their white habits. While it still seemed important to maintain the bonds that united these exiled communities to the motherland-the sine-qua-non conduction to ensure that remittances continued to flow 'home'-it also seemed important to ensure that these exiles stayed where they were, rather than further burdening the Portuguese labour market.

Political elites found the solution to these new challenges of the late 1990s in the Camões Institute. Since 2000, new Camões Cultural Centers were established in Paris and in Poitiers (France), Dakar (Senegal), Windhoek (Namibia), Dili (East Timor), Hamburg (Germany), Stockholm (Sweden) andVienna (Austria), as well as in the headquarters of the African Union in Addis Ababa (Ethiopia) and of the Economic Community of West African States in Abuja (Nigeria). Portuguese Language Centers were opened in Canchungo, Ongoré, Mansoa, Bafatá, Gabú, Buba, Catió, Bolama, Bubaque, and Quinhamel, all in Guinea Bissau, to spread the use of Portuguese as the official language in the country. Taken together, since 1998 the Portuguese state has opened 19 language centres and is now present in 20 cities in different countries. According to Malheiros (2002), 'Portugal's Ministry of Foreign Affairs has registered and attempts to maintain ties with nearly 4.3 million Portuguese and people with Portuguese ancestry living abroad'. ${ }^{8}$ In 2007 , the Camões Institute, together with the Lisbon-based Instituto Superior de Ciências do Trabalho e Empresa (ISCTE) determined that the Portuguese language contributed 17 per cent to the Portuguese GDP. ${ }^{9}$

Portuguese political elites have thus found a way to categorise their citizens into those who can live in Portugal and those who are more functional if and when they stay abroad but send their money home to their families. Neither are all passport-holders welcome in the motherland-as the situation of all those who hold passports, but are treated as foreigners, demonstrates. Conversely, others have been received with open arms, and laws have been changed to accommodate them. The racial project that informs this categorising of people and groups into 'desirable' and 'less-desirable' is hard to overlook. Yet most Portuguese scholars do just that-be it because they cannot find funding for projects that would raise these issues, or because they are too caught up in a hegemonic common sense that has long accepted that non-whites are not Portuguese and thus cannot count on the solidarity of the national community. In so doing, Portuguese academia becomes implicated in the reproduction of a racialised common sense that legitimises the maintenance of a racialised social order, dividing the Portuguese citizenry into first- and second-class citizens. Whereas the white (biological or culturally defined) first-class citizens can count on citizenship rights as entitlements, second-class citizens have not been allowed to live the lives of citizens. The 'asset' nature of citizenship becomes evident, as all those benefiting from such a system have no reason to change it-and instead have every reason to hold the 'Others' out.

\section{Conclusion: Framing Non-Whites and Producing Second-Class Citizens}


An ethnically defined nationalism has become the norm in Western Europe. Although its emergence can be explained by the late-state formation of some EU member-states, such as Germany (Hobsbawm 2003), other states-such as France or Portugal-have only recently shifted away from (in the case of Portugal) or restricted the reach of (in the case of France) the jus soli rules that have long been a cornerstone of their democracies. The contemporary strength of ethnic nationalism must thus be seen as the result of deliberate political action aimed at redrawing the rules of belonging.

Ethnic nationalism, however, not only perpetuates the exclusion of non-whites by defining them as not belonging to the national community; it also stands in the way of the country achieving truly universal citizenship and democracy with strong civil, political and social components. The persistence and even growth of ethnic nationalism is the root of many of the problems which Europe faces today, because it competes with the development of civic bonds among an increasingly heterogeneous European citizenry.

A complication to this problem is caused by the commonly almost exclusive focus on citizenship rights, to the detriment of citizenship duties and responsibilities. Ethnically defined nationalism, coupled with a widely held belief that citizenship is a matter of rights without responsibilities and duties, has created a situation where ethnic white Europeans arrogantly insist on their 'rights' as citizens-thus presenting them as entitlements while conveniently overlooking their responsibilities towards their fellow citizens. Instead, minority citizens get routinely blamed for every and all the economic, social and political problems that many European countries have experienced over the last decades.

The lack of a focus on civic solidarity and of a civically defined European membership is also at the core, I would contend, of the oft-times awkward difficulties many European states and societies have when dealing with antidemocratic elements in their midst. Instead of focusing on anti-democratic agents as the prime culprits of terror and insecurity, blame is commonly shifted away from civic matters towards cultural and ethnic ones-thus unduly blaming certain religions, cultures and ethnic groups for violent acts and 'tendencies', thus further perpetuating stereotypes about others.

To make matters worse, several European states do not provide census data on the ethnic backgrounds of their citizens, justifying such a policy with reference to the principle of universal citizenship. Minority citizens thus have no way of knowing their numbers, situation or degree to which they have a shared destiny. By most accounts, having access to these numbers could prove explosive and is thus avoided by status-quo-oriented political elites. Parallel to not providing census information on European minorities, several European states actively fund a plethora of studies that focus exclusively on immigrants, thus anchoring public attention and discourse firmly on issues of foreigners and their problems of attaining legality and achieving integration. Academia has become implicated in the dissemination of a framework that almost automatically transforms all nonwhites into foreigners and immigrants. There is a clear lack of studies on an increasingly diverse European citizenry and the difficulties of non-white citizens in gaining acceptance, equal opportunities and equal treatment by the state and other-white-citizens. They have become second-class citizens who are not allowed to experience the full extent of the social role that comes with the status of being a citizen. 
Broadly accepted racist practices support the marginalisation of non-white European citizens and expose them to discriminatory practices, and policies, the unchallenged reproduction of which provides evidence for the high degree to which such discrimination has been normalised. Extremely unjust racial regimes are thus being constructed and their victims are being robbed of the tools with which to face up to them effectively.

The influence of European racial regimes becomes even more evident when considering how some migrants, namely ethnic whites, have been able to successfully escape the status of victims. Post-1974 white African immigrants to Portugal have successfully claimed the status of 'returners', which has allowed them to settle unproblematically in Portugal. In 1981 the Portuguese national assembly effectively passed a law restricting Portuguese citizenship to those of Portuguese descent-therefore shifting citizenship criteria from jus soli to jus sanguinis-in order to accommodate white 'returners' and facilitate their integration. But what criterion, if not ethnicity, makes one a 'returner'?

Ethnic nationalism thus is at the core of many problems of contemporary European states and societies. Instead of blaming immigrants, EU memberstates ought to make democracy its foundational element, and membership dependent on citizens' willingness to actively support and defend democracy, which would imply a stronger focus on citizenship responsibilities. But political elites have successfully shifted the focus onto migrants and foreigners and made them the culprits of most of the social problems which European societies face today, allowing those same elites to avoid being blamed for the problems for which they are ultimately responsible. Scholars who, in their studies, focus excessively on immigrants and foreigners, further contribute to a hegemonic common sense that transforms non-whites into foreigners and intruders, thus supporting political elites in their manoeuvring and providing them with legitimacy.

If anything, social scientists should produce more studies on failing and unresponsive states, inefficient bureaucracies, and the dearth of democratic institutions. They should also unveil more of the injustices and problems that a significant part of the European citizenry routinely faces. If they were to do so, we might be able to improve the current situation and work towards more just and inclusive democracies, which might also prove more economically efficient-at least if we believe the Nobel-price winning economist Amartya Sen (2000).

\section{Notes}

[1] It seems important to explain that my own interest in citizenship does not take issue with a whole set of arguments about what rights are and whether or not social reality can be influenced by such lofty concepts as citizenship rights or social rights. I am sceptical about the potential of laws to produce reality and aware of the pitfalls of legal idealism. Citizenship, here, thus does not refer to a set of entitlements. This article is instead concerned with the quality and the conditionalities that restrict the political, civil and social rights of certain individuals and groups within a citizenry. More precisely, I want to analyse how societal dynamics affect and condition the quality of citizenship. Marshall's (1992[1950]) essay had a narrower interest-to analyse the relationship between citizenship and capitalism. He was thus able to see, that the components of a civilized and cultured life, formerly 
the monopoly of the few, were brought progressively within reach of the many, who were encouraged thereby to stretch out their hands towards those that still eluded their grasp. The diminution of inequality strengthened the demand for its abolition, at least with regard to the essentials of social welfare'(1992 [1950]: 37).

[2] Quoted in John Thornhill, Financial Times, 8 November 2005.

[3] TNS SOFRES (2007), survey results available online at http://lecran.org/?p=243.

[4] A search in what is probably the most prestigious academic social-science journal published in Portugal, Analise Social, revealed that, between 2000 and 2009, the journal published 20 articles focusing on migration, but only one on ethnic minorities. Published in 2005, Machado et al. analyse the effects of cultural differences on school performance. Notable exceptions to this tendency of Portuguese academia to render minorities invisible include the work of Fradique (2003), Contador (2001) and Marques et al. (2007).

[5] Interview (my translation) conducted on 10 June 2003 in Lisbon (see Reiter 2008: 409 for complete quote).

[6] Article 1, which specifies original nationality, states that Portuguese by descent are all those born to a Portuguese mother or father in Portuguese territory or in a foreign country if the progenitor was living there and working for the Portuguese state as well as all those born in Portuguese territory or living there over 6 years and working for the Portuguese state who want to adopt Portuguese nationality. ARTIGO 1. ${ }^{\circ}$ (Nacionalidade originária): 1São Portugueses de origem: a) Os filhos de pai português ou mãe portuguesa nascidos em território português ou sob administração portuguesa, ou no estrangeiro se o progenitor português aí se encontrar ao serviço do Estado Português; b) Os filhos de pai português ou mãe portuguesa nascidos no estrangeiro se declararem que querem ser portugueses ou inscreverem o nascimento no registo civil português; c) Os indivíduos nascidos em território português filhos de estrangeiros que aqui residam habitualmente há, pelo menos, seis anos não estejam ao serviço do respectivo Estado, se declararem que querem ser portugueses; d) Os indivíduos nascidos em território português quando não possuam outra nacionalidade. 2-Presumem-se nascidos em território português ou sob administração portuguesa, salvo prova em contrário, os recém-nascidos expostos naqueles territories.

[7] Banco de Portugal (2006) Remittances in the Portuguese Balance of Payments. Luxembourg Group on Remittances, 26-7 June, online: http://www.imf.org/external/np/sta/bop/2006/luxgrp/pdf/italy.pdf.

[8] MPI: http://www.migrationinformation.org/feature/display.cfm?ID=77.

[9] Jornal Publico, 21 January 2009.

\section{References}

Avritzer, L. (2009) Participatory Institutions in Democratic Brazil. Baltimore: Johns Hopkins University Press.

Balibar, E. (2004) We, the People of Europe? Princeton: Princeton University Press. 
Bottomore, T. (1992) "Forty Years On." In: Marshal, T.H. Citizenship and Social

Class. London: Pluto Press, pages 55-93.

Brubaker, R. (1989) Immigration and the Politics of Citizenship in Europe and North America. Lanham: University Press of America.

Brubaker, R. (1992) Citizenship and Nationhood in France and Germany. Cambridge: Harvard University Press.

Contador, A. (2001) Cultura Juvenil Negra em Portugal. Oeiras: Celta.

Da Matta, R. (1987) 'The quest for citizenship in a relational universe', in Wirth, J., Edson de Oliveira Nunes and Thomas Bogenschild (eds) State and Society in Brazil. Boulder: Westview Press, 307-335.

Dworkin, R. (1978) Taking Rights Seriously. Cambridge: Harvard University Press.

Eaton, M. (2001) 'Lusophone-African insertion in Portugal's dual labour market', International Journal of Iberian Studies, 14(3): 157-67.

Fischer, B. (2008) A Poverty of Rights. Stanford: Stanford University Press.

Fradique, T. (2003) Fixar o Movimento: Representações da Música Rap em Portugal. Lisbon:

Publicações Dom Quixote.

Freire, A. (2007) 'Minority representation in Portuguese democracy', Portuguese Journal of Social Science, 6(3): 193-211.

Habermas, J. (1998) Between Facts and Norms. Cambridge: MIT Press.

Hagopian, F. (2007) "Latin American Citizenship and Democratic Theory." In

Tulchin, Joseph and Meg Ruthenberg (eds.) Citizenship in Latin America.

Boulder: Lynne Rienner Publishers, pages 11-56.

Hobsbawm, E. (2003) Nations and Nationalism since 1780. New York: Cambridge University Press.

Holston, J. (2008) Insurgent Citizenship. Princeton: Princeton University Press.

Holston, J. (2007) "Citizenship in Disjunctive Democracies." In Tulchin, Joseph and Meg Ruthenberg (eds.). Citizenship in Latin America. Boulder: Lynne Rienner Publishers, pages 75-94.

Hortas, M.J. (2008) 'Territories of integration: the children of immigrants in the schools of the Metropolitan Area of Lisbon', Intercultural Education, 19(5): 421-33.

Jones, E. and Gaventa, J. (2002) Concepts of Citizenship: A Review. Brightob: Institute of Development Studies.

Kiwan, N. (2007) 'Equal opportunities and republican revival: post-migrant politics in contemporary France', International Journal of Francophone Studies, 10(12): $157-72$.

Kuhn, T. (1996) The Structure of Scientific Revolutions. Chicago: University of Chicago Press.

Luxembourg Group of Remittances (2006) Remittances in the Portuguese Balance of Payments. Lisbon: Banco de Portugal: www.imf.org/external/np/sta/bop/2006/luxgrp/pdf/portug.pdf.

Machado, F.L., Matias, A.R. and Leal, S. (2005) 'Desigualdades sociais e diferencas culturais: os resultados escolares dos filhos de imigrantes africanos', Analyse Social, 40(3): 695-714.

Malheiros, J. (2002) "Portugal Seeks Balance of Emigration, Immigration." Migration Policy Institute, available online: www.migrationinformation.org/feature/display.cfm?ID=77. 
Marques, M., Valente Rosa, M.J. and Lopes Martins, J. (2007) 'School and diversity in a weak state: the Portuguese case', Journal of Ethnic and Migration Studies, 33(7):1145-68.

Marshall, T.H. (1992 [1950]) Citizenship and Social Class. London: Pluto Press.

O'Donnell, G., Cullell, J.V. and lazzetta, O. (eds) (2004) The Quality of Democracy. Notre Dame: University of Notre Dame Press.

Pinheiro, T. (2008) 'Emigration, immigration and interculturality: the meaning of the European Year of Intercultural Dialogue in Portugal', Eurolimes: Journal of the Institute for Euroregional Studies, 6: 63-73.

Pires, R.P. (2003) Migracoes e Integracao. Teoria e Aplicacoes a Sociedade Portuguesa. Oeiras: Celta.

Popper, K. (2002) The Logic of Scientific Inquiry. London: Routledge.

Popper, K. (1962) The Open Society and Its Enemies. Vol 1. Princeton: Princeton University Press

Reiter, B. (2009) Negotiating Democracy in Brazil. Boulder: New Forum Press.

Reiter, B. (2008) 'The perils of empire: nationhood and citizenship in Portugal', Citizenship Studies, 12(4): 397-412.

Rosello, M. (2001) Postcolonial Hospitality: The Immigrant as Guest. Stanford: Stanford University Press.

Sandel, M. (1998) Democracy's Discontent. New York: Belknap.

Sen, A. (2000) Freedom as Development. Cambridge: Harvard University Press.

Silberman, R., Alba, R. and Fournier, I. (2007) 'Segmented assimilation in France? Discrimination in the labour market against the second generation', Ethnic and Racial Studies, 30(1): 1-27.

Simon, P. (2003) 'France and the unknown second generation: preliminary results on social mobility', International Migration Review, 37(4): 1091-119.

Somers, M. (1993) 'Citizenship and the Place of the Public Sphere: law, community, and political culture in the transition to democracy', American Sociological Review, 58. No.5 (Oct.1993): 587-620.

Tin, L.-G. (2008) 'Who is afraid of blacks in France?', French Politics, Culture and Society, 26(1): 32-44.

Tulchin, J. and Ruthenberg, M. (2007) Citizenship in Latin America. Boulder: Lynne Rienner.

Winant, H. (2001) The World is a Ghetto. New York: Basic Books.

Young, I.M. (1990) Justice and the Politics of Difference. Princeton: Princeton University Press. 